report is essentially a factual account of this first stage and any firm conclusions must await the result of using a piece of test equipment in a test programme for which the National Science Foundation has awarded a further grant. Meanwhile besides describing the general organization of the programme and giving a detailed analysis of the problems encountered, the report includes various statistical details and an account of some supplementary indexing undertaken by other organizations and individuals in co-operation. When the test programme is completed it should be possible to analyse the results so as to ascertain in detail the reasons for success or failure in locating information and eventually to state with reasonable certainty exactly what requirements an information retrieval system must meet and propose methods for the design of such a system.

\section{Co-ordination of Research}

A VALUABLE means of co-ordinating research in engineering over an 'academic' region is being carried out by the Academic Board for Higher Technology of the Northern Advisory Council for Further Education (Thirteenth Annual Report, 1959/1960. Pp. 32. Newcastle upon Tyne: Northern Advisory Council for Further Education, 1960). The Board has accepted proposals put forward by Prof. W. Fisher Cassie, of the University of Durham, in which he recommended that the institutions for higher technology in the region should be asked to send to the Board their proposals for research projects. In this way, "the Board would be informed of the whole pattern of research and would be able to advise on the use of expensive apparatus and on the possibility of a number of institutions sharing in a research of some magnitude". The Board also accepted recommendations put forward by Prof. A. F. Burstall that more provision should be made for training in engineering design. As a first step a sub-committee was appointed to report on the organization of short courses for designers. Industry will warmly welcome this initiative.

\section{Magnetic Data for the International Geophysical Year}

THE 1957 and 1958 volumes of the Observatories' Year Book covering the International Geophysical Year have recently been published (Air Ministry, Meteorologieal Office. The Observatories' Year Book. 1957. Pp. vi+120. (M.O. 680.) $50 s$. net. 1958. Pp. vi +128 . (M.O. 681.) 55s. net. London: H.M. Stationery Office, 1960). They contain the autographic records and eye observations of terrestrial magnetism at Lerwick and Eskdalemuir observatories and of atmospheric electricity at Lerwick and Kew. They also contain the log of the auroral watch at Lerwick and a general auroral table for the British Isles. These two volumes have been published out of turn, the otherwise latest volume published being that for 1950 , in order to make the fundamental magnetic observations made at the Scottish observatories during the International Geophysical Year available to geophysicists as early as possible. The volumes for 1951-56 are expected to be published during the next twelve months.

\section{The Sarawak Museum Journal}

The Sarawak Museum Journat, under the enthusiastic editorship of $\mathrm{Mr}$. Tom Harrisson, Government ethnologist and curator of the Museum, is always of interest to many outside Borneo. The current issue
(9, No. 13-14 (New Series), July-December 1959) includes papers on ethnology, history, prehistory, Welfare States, natural history and some book reviews. Notes on "An All-round Museum in a small Country" are as applicable elsewhere as they are in Borneo. Other articles include some carbon-14 datings from Niah caves, an account of the Piltdown forgery from the point of view of orang-utang teeth from Borneo or Sumatra, and notes on cock-fighting, the Dayah national game.

\section{Education in the Primary School}

To help teachers in primary schools, the National Union of Teachers is issuing a new series called "Curriculum Studies". The first, "Mathematics in the Primary School", has been prepared by R. A. Swallow, who has specialized in the teaching of mathematics to primary school children over many years. The booklet is clearly written, full of problems which can be presented to children at differing ages, and based on his own experience of children. The second, "Science in the Primary School", explains how science in the primary school should be developed and describes means of doing this. The author, Cedric Griggs, should now follow the sequence of Mr. Swallow's booklet and present a programme of science teaching to develop coincidentally with young children's emerging interests. Both booklets can be obtained from the Schoolmaster Publishing Co., Hamilton House, Hastings Street, London, W.C.1, the former price $2 s .6 d$. and the latter $2 s$.

\section{New Technique in Insulation Testing}

The new 'Megger' insulation tester, series 3, mark 3, manufactured by Evershed and Vignoles, Ltd., incorporates some advanced features made possible by new manufacturing techniques and materials. The instrument consists of a hand-driven generator and a direct-reading ohmmeter. The moving element of the ohmmeter consists of two coils, the control and deflecting coils, arranged so as to oppose each other. There is no control spring and the deflexion of the movement depends on the ratio of the currents in the two coils. The turning effort of the new instrument is considerably less than that required for earlier models. A clutch-less nylon geartrain transmits the handle torque to the generator and provides remarkably smooth and consistent operation. In addition to the insulation testing range, the instrument operates over a continuity range 0-100 ohms with a scale of shape permitting readings as low as $0.1 \mathrm{ohm}$. The continuity testing voltage is obtained from a new miniature generator so that no battery is required and thus constant readiness for use is ensured.

\section{Evaluation and Presentation of Spectro-Analytical Results}

IN the pocket booklet entitled "Evaluation and Presentation of Spectro-Analytical Results" the author, A. B. Calder, directs attention to the various types of error which arise in chemical and instrumental analysis (London: Hilger and Watts, Ltd., 1959. 5s. net). The errors are classified into two groups, determinate or constant errors, and indeterminate or accidental errors. Their mathematical treatment is dealt with in some detail and then finally the application of the treatment to various spectro-analytical problems is discussed. Throughout, references are given to fuller treatments, 